\title{
Selection of Best Power Supply Source for Telecom Towers in Remote Areas
}

\author{
Shwetank Avikal \\ Department of Mechanical Engineering, \\ Graphic Era Hill University, Dehradun, Uttarakhand, India. \\ Corresponding author: shwetank.avikal@gmail.com \\ Rahul Singhal \\ Department of Mechanical Engineering, \\ Graphic Era Hill University, Dehradun, Uttarakhand, India. \\ E-mail: rahulsinghak7777@gmail.com \\ Rajat Sajwan \\ NIFCO India Private limited, Gurugram, Haryana, India. \\ E-mail: rajat.sajwan007@gmail.com

\section{Rahul Kumar Tiwari} \\ Department of Mechanical Engineering, \\ Graphic Era Hill University, Dehradun, Uttarakhand, India. \\ E-mail: rahulkrtiwari07@gmail.com

\section{Rohit Singh} \\ Infosys Private Limited, Bhubaneshwar, Odisha, India. \\ E-mail: rohitmajila@gmail.com
}

(Received December 11, 2019; Accepted April 25, 2020)

\begin{abstract}
Installation of telecom towers in remote areas especially in developing countries like India is a major problem for telecom industries because of the unavailability of reliable power supply. The grid supply is not regular in these countries and up to some extent, they are dependent on diesel generators for power supply. But these diesel generators have some major issues such as high operating cost due to high cost of fuel, transportation cost of fuel, high maintenance cost, and these diesel generators also emits pollution to the environment. In presented work, an approach has been proposed for telecom companies for providing power supply to their telecom towers. An economic cost analysis has been proposed by considering various criteria such as cost, air \& noise pollution and reliability, etc. Some power supply alternatives including unconventional and hybrid of conventional and unconventional alternatives have been compared to find the solution such as diesel-powered telecom towers, solar powered telecom towers, and their hybrids. The main objective of this work is to provide a reliable, cost effective and environment friendly Remote Area Power Supply (RAPS) system for a particular site in India (Uttar Pradesh). A number of criteria are involved in discussed problem in order to select an effective power supply source. Therefore, the problem has been considered as a Multi Criteria Decision Making (MCDM) problem. To select the best alternative, a Fuzzy AHP and TOPSIS based approach has been proposed. Fuzzy AHP (Analytic Hierarchy process) has been used for calculating the weightage of criteria and the concept of Technique for Order of Preference by Similarity to Ideal Solution (TOPSIS) has been applied for ranking the alternatives. The results give assured reliability and sustainability for remote areas using a solar photovoltaic (PV)-diesel generator hybrid energy system.
\end{abstract}

Keywords- Telecom tower, Cost and energy optimization, Hybrid energy system, Solar PV, Economic cost analysis, MCDM, Fuzzy AHP, TOPSIS. 
International Journal of Mathematical, Engineering and Management Sciences

Vol. 5, No. 5, 913-925, 2020

https://doi.org/10.33889/IJMEMS.2020.5.5.070

\section{Introduction}

The tremendous increment in the number of mobile phone subscribers has led to unexpected growth in the telecom towers industry in India. Due to geographical limitations, there is the unavailability of grid supply in some interior rural areas. Grid supply is also not available properly in most of the rural areas across the country. Therefore, grid supply is not a reliable power source to supply the electricity to the telecom towers situated in interior rural areas anywhere in the country because it requires 24 hours of continuous supply. To provide the power during break down period, a number of other sources are in practice and diesel generator sees very common among them. Diesel generators have some common issues such as their high running cost, maintenance cost, noise, and air $\left(\mathrm{SO}_{\mathrm{x}}, \mathrm{CO}_{\mathrm{x}}\right.$, and $\left.\mathrm{NO}_{\mathrm{x}}\right)$ pollution emitted to the environment.

These disadvantages have forced the companies to search for other alternatives for reducing the cost and pollution produced by the diesel generator. Renewable energy sources may be the best alternatives to overcome the effect of above discussed problems. A hybrid source of energy may be the best solution for this type of problem. The availability of these sources is again an issue because solar and wind are easily available but hydropower, geothermal power, biomass, etc. are not easily available everywhere.

To select the best hybrid energy system, the first step is to analyze the economic cost by considering various criteria such as total cost (CAPEX AND OPEX) air and noise pollution, and reliability of the system. A number of available solutions can be compared to find the most suitable solution among diesel powered telecom towers, grid powered telecom towers, solar powered telecom towers, hybrid system of grid and diesel, hybrid system of grid-diesel-battery bank, the hybrid system of solar and diesel, the hybrid system of solar and grid. A case study has been conducted to obtain a reliable, cost effective and environment friendly remote area power supply (RAPS) system for a particular site (Mohand, near Daat Kali Temple) in India (Uttar Pradesh) for installation of a telecom tower.

To find out the most suitable alternative solution, the concept of Multi Criteria Decision Making (MCDM) approach has been highly recommended for solving discussed types of problem. The given problem has also been considered on an MCDM problem and an approach based on FUZZY AHP \& TOPSIS has been proposed to solve this problem.

\section{Background}

Several studies have been conducted focusing on different energy aspects to design hybrid systems for solving similar types of problems.

Gabler and Luther (1988) have experimented with several simulations on a wind-solar-fuel hybrid energy system. Techniques of energy conservations validate that the resultant energy of the hybrid system is more robust than the singular system. Gupta et al. (2007) have proposed an approach to develop a solar-wind powered hybrid system considering that desired power should be developed. Zhou (2008) has shown the different aspects of the solar-wind hybrid energy and found that the limitations of their singular system and found that it can be overcome by making them hybrid. Ekren and Ekren (2009) have optimized a hybrid solar photovoltaic-wind-battery supported power system using a simulation approach. They have optimized it to decrease the whole hybrid setup cost. Bajpai et al. (2009) have studied different hybrid power systems such as a Solar Photovoltaicbattery bank hybrid system, a Solar Photovoltaic-fuel cell hybrid system, and a Solar PhotovoltaicFuel cell-battery hybrid system. They found that the first one is more efficient and safer. 
International Journal of Mathematical, Engineering and Management Sciences

Vol. 5, No. 5, 913-925, 2020

https://doi.org/10.33889/IJMEMS.2020.5.5.070

Prasad et al. (2010), Muralikrishna and Lakshminarayana (2011) have optimized the solar PVwind hybrid power system by installing sun tracking techniques and wind speed regulation and have also used the microcontrollers to improve the tracking mechanism to obtain high energy. Ajao et al. (2011) have simulated the cost of a solar PV- wind energy system and the cost of an electrical grid powered system, and it was also analyzed that the first one was much better than another one. Lal et al. (2011) have optimized a solar PV-wind-hydro-diesel generator hybrid system using the Hybrid Optimization Model for Electric Renewables (HOMER) software. Moury et al. (2012) have proposed a hybrid solar PV- diesel generator system for a telecom site in Bangladesh. Rath et al. (2012) have proposed that the use of a solar-wind hybrid energy system, can upgrade the system's sustainability and reliability and the power supply cost can be reduced for providing $4.75 \mathrm{KW}$ electrical supply the telecom site. In their study, the diesel generator was set up only as a backup so as to use it in case of emergencies and cloudy weather.

Anayochukwu and Nnene (2013) have studied the possibility of making a hybrid solar PV-diesel generator energy system for a telecom site in Nigeria and found it more suitable and efficient. Martinez-Diaz et al. (2013) have proposed a solar photovoltaic-wind-diesel generator-battery bank hybrid energy system for a telecom site in Spain and found it as cost effective system. Kusakana and Vermaak (2013) have proposed a solar PV-wind hybrid energy system for a telecom site in remote areas of the Republic of the Congo to provide a continues to supply and found it better. Amer et al. (2013) have investigated a hybrid power system so as to reduce the cost of the supply by using the approach of Particle Swarm Optimization (PSO). Lorincz and Bule (2013) have proposed that renewable energy sources like solar, wind, and their combination with fuel cells can be used to supply power to base stations and hence can further be used to reduce energy costs and increase the efficiency of energy in remote areas. Ani (2014) has proposed an algorithm to control and oversee the operations of a PV-Wind-Diesel hybrid power generation system for GSM base station sites. The algorithm was designed in a way to maximize the use of renewable energy systems while limiting the use of diesel generator for power generation. Alsharif et al. (2015) have investigated the possibility of the solar PV- diesel hybrid energy system to deliver power to rural BSs of Malaysia to minimize both the OPEX and pollution emission. Acakpovi et al. (2015) have developed an algorithm to optimize the cost of a solar PV-hydro-wind hybrid power system. Çolak and Kaya (2017) have proposed that renewable energy sources can be used to tackle the problem of energy requirements in Turkey. They used the concept of AHP, MCDM, and TOPSIS, so as to find the best alternative renewable energy sources.

In the presented literature, it has been seen that many renewal energies resources have been proposed for solving different types of energy problems. A number of optimization approaches have also been proposed for optimizing the energy resources for different problems. But very few of them have reported the real-life problem of developing countries just like India. In proposed work, a real-life problem has been discussed and an optimum solution has been proposed for solving the problem with the help of MCDM techniques.

\section{Solution Approach}

\subsection{Fuzzy AHP (Analytic Hierarchy Process)}

AHP is an orderly technique used to estimate the relative importance between two or more attributes by means of pairwise comparisons ( $\mathrm{Ng}, 2016)$. In AHP, preferences among alternatives can be determined by pair wise comparisons. These comparisons can be made by using a preference with scale. The existing form of AHP which uses a simple nine-point scale (1-9) (Table 1) seems insufficient to deal with the problem of uncertainty. Therefore, to deal with this type of uncertainty 
International Journal of Mathematical, Engineering and Management Sciences

Vol. 5, No. 5, 913-925, 2020

https://doi.org/10.33889/IJMEMS.2020.5.5.070

an extension of AHP known as Fuzzy AHP has been used.

Table 1. Scaling: (as per Satty table)

\begin{tabular}{|c|c|c|c|c|c|c|c|c|}
\hline $\begin{array}{c}\text { Equal } \\
\text { importance }\end{array}$ & $\begin{array}{c}\text { Weak or } \\
\text { slight }\end{array}$ & Moderate & $\begin{array}{c}\text { Moderate } \\
\text { plus }\end{array}$ & $\begin{array}{c}\text { Strong } \\
\text { importance }\end{array}$ & $\begin{array}{c}\text { Strong } \\
\text { plus }\end{array}$ & $\begin{array}{c}\text { Very } \\
\text { strong }\end{array}$ & $\begin{array}{c}\text { Very, } \\
\text { very } \\
\text { strong }\end{array}$ & $\begin{array}{c}\text { Extreme } \\
\text { importance }\end{array}$ \\
\hline 1 & 2 & 3 & 4 & 5 & 6 & 7 & 8 & 9 \\
\hline
\end{tabular}

Fuzzy AHP method is a systematic approach to the alternative selection and justifies the problem by using the concepts of fuzzy set theory and hierarchical structure analysis. The decision-maker can specify preferences in the form of natural language or numerical value about the importance of each performance attribute (Chand and Avikal, 2015; Chand et al., 2017).

\subsection{The Technique for Order Preference by Similarity to Ideal Solutions (TOPSIS)}

Hwang and Yoon (1981) proposed a method for ranking of different alternatives by increasing their relative distance from 2 hypothetical solutions named as the positive and negative idle solution. Here, the domain of alternative was defined as an n-dimension Euclidean space, and every alternative was presented as point in space. According to the theory of TOPSIS, the alternative at farthest from negative idle solution and closed to the positive idle solution will be preferred over another alternative (Avikal et al., 2014).

Step 1. Establish a normalized decision matrix. NM this matrix shows are the relative performance of alternatives, $N M_{a, c}$.

$$
N M_{a, c}=\left[b_{a c}-\min \left(b_{a c}\right)\right] /\left[\max \left(b_{a c}\right)-\min \left(b_{a c}\right](a=1,2, \ldots n ; c=1,2, \ldots s)\right.
$$

Where $b_{a c}$ is the performance measure of $a^{\text {th }}$ alternative with respect to $c^{\text {th }}$ criterion.

For non-beneficial criteria, Eqn. (1) can be rewritten as follows:

$$
N M_{a, c}=\left[\max \left(b_{a c}\right)-b_{a c}\right] /\left[\max \left(b_{a c}\right)-\min \left(b_{a c}\right)\right]
$$

Step 2. Calculation of weighted decision (WM) matrix by simply multiplying the weight matrix to the NM, then $W M=\left\{k_{a, c} \mid a=1,2, \ldots n ; c=1,2, \ldots s\right\}$

$$
k_{a, c}=W_{a} \frac{b_{a, c}}{\sqrt{\sum_{c=1}^{s} b_{a, c}^{2}}}
$$

where $W_{a}$ is the weight of $a^{\text {th }}$ alternative. 
Step 3. Calculation of PS and NS by using WM:

$$
\begin{aligned}
& P S=\left\{\left(\max _{c} k_{a, c} \mid a \in X\right) \operatorname{or}\left(\min _{c} k_{a, c} \mid a \in X^{\prime}\right) \mid c=1,2, \ldots S\right\} \\
& =\left(k_{1}^{+}, k_{2}^{+}, \ldots, k_{n}^{+}\right) . \\
& N S=\left\{\left(\min _{c} k_{a, c} \mid a \in X\right) \operatorname{or}\left(\max _{c} k_{a, c} \mid a \in X^{\prime}\right) \mid c=1,2, \ldots S\right\} \\
& =\left(k_{1}^{-}, k_{2}^{-}, \ldots, k_{n}^{-}\right) .
\end{aligned}
$$

where $X=\left\{a=1,2, \ldots, n\right.$ and $a$ is associated with the beneficial customer requirements of $\left.k_{a, c}\right\}$, and $X^{\prime}=\left\{a=1,2, \ldots, n\right.$ and $a$ is associated with the cost-effective customer requirements of $k_{a, c}$ \} .

Step 4. Calculation of each alternative from PS and NS.an Euclidean distance method will be used in presented work

$$
\begin{aligned}
& k_{c}^{+}=\sqrt{\sum_{a=1}^{n}\left(k_{a, c}-k_{a}^{+}\right)^{2}}, c=1,2, \ldots, s \\
& k_{c}^{-}=\sqrt{\sum_{a=1}^{n}\left(k_{a, c}-k_{a}^{-}\right)^{2}}, c=1,2, \ldots, s
\end{aligned}
$$

Step 5. Calculation of relative closeness (RC) to both idle solutions for each alternative.

$$
R Y_{c}=\frac{k_{c}^{-}}{k_{c}^{+}+k_{c}^{-}}, c=1,2, \ldots, s \text { and } 0 \leq R Y_{c} \leq 1
$$

Step 6. Ranking of alternatives according to their relative closeness to the idle solution. The alternative will be ranked according to the higher relative closeness and will be preferred according to their rank.

\subsection{Case Study}

\subsubsection{Problem Definition}

The site "Mohand Uttar Pradesh, India" has been selected because the mobile phone signals are not available and no grid power supply is available. A hybrid energy system has been proposed to solve these types of problems that can also be applied to other similar issues. The selected site/location is located at a distance of about $10 \mathrm{Km}$ from the grid power supply source that is available at Dat Kali Temple. The study aims to suggest an energy source/ system that can fulfill the demand of $4 \mathrm{KW} / \mathrm{h}$ to successfully operate the telecom tower and in a cost effective and environment friendly manner. Some hybrid energy sources (alternative) have been considered to find out the solution of the problem on the basis of a number of criteria such as Reliability, pollution, and total cost, etc. the problem has been considered as a Multi Criteria Decision making (MCDM) problem and a Fuzzy AHP and TOPSIS based approach has been proposed for solving the problem. 
International Journal of Mathematical, Engineering and Management Sciences

Vol. 5, No. 5, 913-925, 2020

https://doi.org/10.33889/IJMEMS.2020.5.5.070

\subsubsection{Energy Sources Available at Location}

The data and information have been taken for Dehradun, Uttarakhand as "Mohand", Uttar Pradesh shares boundary with Dehradun, Uttarakhand. The selected is about 20 to $25 \mathrm{~km}$ away from Dehradun, Uttarakhand and hence, the metrological data provided is the same for both the places. The different alternative energy resources selected for this site are mentioned as following:

\subsubsection{Wind Energy Resource}

This data has been derived from the website www.worldweatheronline.com. The average annual wind velocity in Uttarakhand is between 4 to 5 miles per hour (mph). Average monthly wind velocity in $\mathrm{mph}$ is shown in Table 2 . below:

Table 2. Wind velocity in mph

\begin{tabular}{|l|c|}
\hline Month & Wind velocity \\
\hline January & 4.0 \\
\hline February & 4.9 \\
\hline March & 6.0 \\
\hline April & 7.2 \\
\hline May & 7.2 \\
\hline June & 5.1 \\
\hline July & 3.1 \\
\hline August & 2.9 \\
\hline September & 3.8 \\
\hline October & 4.5 \\
\hline November & 4.5 \\
\hline December & 3.6 \\
\hline
\end{tabular}

This data shows the average annual wind velocity that is very low and the flow of wind is in nonuniform. Hence, wind sources of energy cannot be used for our energy system and therefore, eliminated from this study.

\subsubsection{Solar Energy Resource}

This data has been derived from the website www.synergyenviron.com. The average annual solar radiation in Uttarakhand is between 4 to $7 \mathrm{~kW}-\mathrm{hr} / \mathrm{m}^{2} /$ day. Due to its geographical location, it receives an abundance of solar radiation. The average monthly solar radiation in $\mathrm{KW}-\mathrm{hr} / \mathrm{m}^{2} /$ day is shown in Table 3 .

Table 3. Solar radiation in $\mathrm{KW}-\mathrm{hr} / \mathrm{m}^{2} /$ day

\begin{tabular}{|l|c|}
\hline Month & Solar Radiation \\
\hline January & 5.65 \\
\hline February & 5.89 \\
\hline March & 6.36 \\
\hline April & 6.02 \\
\hline May & 6.12 \\
\hline June & 4.38 \\
\hline July & 2.45 \\
\hline August & 2.54 \\
\hline September & 4.22 \\
\hline October & 7.06 \\
\hline November & 7.55 \\
\hline December & \multicolumn{2}{|c|}{7.12} \\
\hline
\end{tabular}


International Journal of Mathematical, Engineering and Management Sciences

Vol. 5, No. 5, 913-925, 2020

https://doi.org/10.33889/IJMEMS.2020.5.5.070

This study shows that Uttarakhand has a moderate climate throughout the year. Furthermore, solar PV cells are highly reliable, have fewer maintenance costs, and produce no pollution. Thus, solar energy can be used for powering telecom towers.

\subsubsection{Alternative Energy Sources}

Alternative energy sources for the hybrid energy system to supply power to meet a load of $4 \mathrm{KW}$

(i) Grid Supply: A power grid supply can be installed near the selected site that can provide the power for 24 hours. The installation cost (CAPEX) for this system will be about INR $4,610,850$, it will contain all the costs such as cost of poles, wires, and labor, etc. and the operating cost (OPEX) will be about INR 4,6981.6 per month (the cost of electricity is about INR 6 per unit).

(ii) Diesel Generators: In this power source, 3 generators will have to be installed. 2 of them will work for 24 hours (12 hours each) and the third one will be used as a backup to maintain the power supply in the case of any emergency.

(iii) Grid Supply + Diesel Generator: In this power source, a power grid and a diesel generator will be installed with the assumption that the grid will be able to supply power up to 18 hours and the rest of 6 hours, diesel generator well supply the power.

(iv) Grid Supply + Diesel Generator + Battery Bank: In this case, a grid will be installed along with a diesel generator and a battery bank. It has been assumed that the grid will supply the power for 12 hours and the next 12 hours the other supporting system will provide the same i.e. diesel generator will work for 6 hours and the battery bank will work for 6 hours.

(v) Solar PV System + Battery Bank: In this system, a solar panel will be installed with a battery bank. It is known that the solar panel cannot work for 24 hours continuously and can work only in sunlight for a maximum of 8-9 hours per day. Here, the energy required for the other 16 hours will be generated in the availability of sunlight and will be stored in the battery bank.

(vi) Solar PV System + Battery Bank + Diesel Generator: This system is similar to the above system and there is only one difference as compared to the above i.e. a diesel generator. In this case, it has been assumed that there may be a case of any emergency such as low sunlight, clouded weather, and other similar cases, the diesel generator will provide the power and it will work for an average of 4 hours per day.

(vii) Solar PV System + Battery + Grid Supply: In this alternative, a solar panel will be installed with a battery bank and a grid supply. It is to be assumed that solar energy will not be available for the whole day and the battery bank will work as a backup when sunlight is not available if the case grid supply will not work then the battery will help us to do the same. Grid supply is supposed to work for 10 hours in a day and Battery will get charged during the sun time and store the energy for backup when PV solar system shuts down during a power outage and supply the power whenever is necessary. The data of all the alternatives based on selected criteria have been shown in Table 4. 
International Journal of Mathematical, Engineering and Management Sciences

Vol. 5, No. 5, 913-925, 2020

https://doi.org/10.33889/IJMEMS.2020.5.5.070

Table 4. Data of all the alternatives based on criteria

\begin{tabular}{|l|c|c|l|l|l|}
\hline $\begin{array}{l}\text { Criteria } \\
\text { Alternative }\end{array}$ & $\begin{array}{l}\text { Opex (running } \\
\text { cost } \\
\text { maintenance cost) } \\
\text { (in rupees) }\end{array}$ & $\begin{array}{l}\text { Capex (equipment and } \\
\text { installation cost, } \\
\text { considering life cycle of } \\
\text { equipment) (in rupees) }\end{array}$ & $\begin{array}{l}\text { Air } \\
\text { pollution }\end{array}$ & $\begin{array}{l}\text { Noise } \\
\text { pollution }\end{array}$ & Reliability \\
\hline $\begin{array}{l}\text { Grid Supply } \\
\text { (24 Hrs) }\end{array}$ & $1,25,10,491$ & 3.1 crores & $\begin{array}{l}\text { Weak or } \\
\text { slight }\end{array}$ & $\begin{array}{l}\text { Weak or } \\
\text { slight }\end{array}$ & Moderate \\
\hline $\begin{array}{l}\text { Diesel Generator } \\
\text { (24 Hrs) }\end{array}$ & $3,40,14,055$ & 1.2 crores & $\begin{array}{l}\text { Very } \\
\text { strong }\end{array}$ & Moderate & $\begin{array}{l}\text { Moderate } \\
\text { plus }\end{array}$ \\
\hline $\begin{array}{l}\text { Gs } \\
\text { (18 Hrs) + D.G (6 Hrs) }\end{array}$ & $1,92,43,857$ & 3.5 crores & $\begin{array}{l}\text { Moderate } \\
\text { plus }\end{array}$ & Moderate & $\begin{array}{l}\text { Moderate } \\
\text { plus }\end{array}$ \\
\hline $\begin{array}{l}\text { Gs (12 Hrs) + D.G (8 Hrs) + Battery } \\
\text { Bank (4 Hrs) }\end{array}$ & $2,02,47,882$ & 4 crores & $\begin{array}{l}\text { Moderate } \\
\text { plus }\end{array}$ & Moderate & $\begin{array}{l}\text { Moderate } \\
\text { plus }\end{array}$ \\
\hline $\begin{array}{l}\text { (Solar + Battery Bank) } \\
\text { (24 Hrs) }\end{array}$ & $21,71,960$ & 3.2 crores & $\begin{array}{l}\text { Weak or } \\
\text { slight }\end{array}$ & $\begin{array}{l}\text { Weak or } \\
\text { slight }\end{array}$ & $\begin{array}{l}\text { Strong } \\
\text { importance }\end{array}$ \\
\hline $\begin{array}{l}\text { (Solar + Battery Bank) } \\
\text { (20 Hrs) + D.G (4 Hrs) }\end{array}$ & $93,49,275$ & 3.1 crores & Moderate & $\begin{array}{l}\text { Weak or } \\
\text { slight }\end{array}$ & Very strong \\
\hline $\begin{array}{l}\text { (Solar + Battery Bank) (14 Hrs) } \\
\text { + Gs (10 Hrs) }\end{array}$ & $73,84,665$ & 4.6 crores & $\begin{array}{l}\text { Weak or } \\
\text { slight }\end{array}$ & $\begin{array}{l}\text { Weak or } \\
\text { slight }\end{array}$ & $\begin{array}{l}\text { Moderate } \\
\text { plus }\end{array}$ \\
\hline
\end{tabular}

Summation of OPEX and CAPEX are shown in Table 4 and have been taken and with the help of Table 1, the data of Table 4 has been converted to the numerical form from the crisp form and has been shown in Table 5.

Table 5. Modified data of all the alternatives based on criteria

\begin{tabular}{|c|c|c|c|c|}
\hline $\begin{array}{l}\text { Criteria } \\
\text { Alternative }\end{array}$ & $\begin{array}{l}\text { Total Cost }(\text { Opex + Capex) } \\
\text { (In Rupees) }\end{array}$ & Air Pollution & Noise Pollution & Reliability \\
\hline Grid Supply (24 Hrs) & 43510491 & 2 & 2 & 3 \\
\hline Diesel Generator (24 Hrs) & 46014055 & 7 & 3 & 4 \\
\hline Gs (18 Hrs) + D.G (6 Hrs) & 54243857 & 4 & 3 & 4 \\
\hline $\begin{array}{l}\text { Gs (12 Hrs) + D.G (8 Hrs) + Battery } \\
\text { Bank (4 Hrs) }\end{array}$ & 60247882 & 4 & 3 & 4 \\
\hline (Solar + Battery Bank) (24 Hrs) & 34171960 & 2 & 2 & 5 \\
\hline $\begin{array}{l}(\text { Solar + Battery Bank }) \\
(20 \mathrm{Hrs})+\text { D.G }(4 \mathrm{Hrs})\end{array}$ & 40349275 & 3 & 2 & 7 \\
\hline $\begin{array}{l}\text { (Solar + Battery Bank) } \\
(14 \mathrm{Hrs})+\mathrm{Gs}(10 \mathrm{Hrs})\end{array}$ & 53384665 & 2 & 2 & 4 \\
\hline
\end{tabular}

\section{Application of Fuzzy AHP:}

All the criteria have been compared with each other for evaluating the weights of each criterion. The comparison matrix of criteria has been shown in Table 6, and the weight of each criterion has been shown in Table 8. In order to control the results, the consistency ratio (CR) for the matrix has been by using following equations (9) and (10), and the value of the random index has been selected from Table 7:

$\mathrm{CI}=\frac{\lambda_{\max }-n}{n-1}$

where, $\mathrm{CI}=$ consistency index,$\lambda_{\max }=$ Maximum fuzzy Eigenvalue, $n=$ No. of criterion. 
International Journal of Mathematical, Engineering and Management Sciences

Vol. 5, No. 5, 913-925, 2020

https://doi.org/10.33889/IJMEMS.2020.5.5.070

Table 6. Fuzzy AHP comparison matrix

\begin{tabular}{|l|c|c|c|c|}
\hline & Total cost & Air pollution & Noise pollution & Reliability \\
\hline Total cost & 1 & 3 & 5 & 1 \\
\hline Air pollution & $\frac{1}{\tilde{3}}=0.375$ & 1 & 2 & $\frac{1}{\tilde{3}}=0.375$ \\
\hline Noise pollution & $\frac{1}{\tilde{5}}=0.2083$ & $\frac{3}{\tilde{5}}=0.508$ & 1 & $\frac{1}{\tilde{5}}=0.2083$ \\
\hline Reliability & $\frac{1}{\tilde{1}}=0.75$ & 3 & 5 & 1 \\
\hline
\end{tabular}

Table 7. Random index

\begin{tabular}{|l|l|l|l|l|l|l|l|l|l|}
\hline Matrix Rank & 2 & 3 & 4 & 5 & 6 & 7 & 8 & 9 & 10 \\
\hline RI & 0.00 & 0.58 & 0.90 & 1.12 & 1.24 & 1.35 & 1.41 & 1.45 & 1.49 \\
\hline
\end{tabular}

$\mathrm{CR}=\frac{\mathrm{CI}}{\mathrm{RI}}$

Table 8 . Weights of criteria calculated by fuzzy-AHP

\begin{tabular}{|l|l|l|}
\hline Criteria 1 & 0.399967 & CI $=0.008287$ \\
\cline { 1 - 2 } Criteria 2 & 0.148229 & CR $=0.009208$ \\
\cline { 1 - 2 } Criteria 3 & 0.078623 & \\
\hline Criteria 4 & 0.373181 & \\
\hline
\end{tabular}

where RI has been selected from Table 7 according to the rank of the matrix i.e. in this case, the matrix rank is 4 and hence the corresponding value of RI to it is 0.90 . The results have shown that the value of $\mathrm{CR}$ is less than 0.1 , hence the data derived from the experts is consistent.

\section{Application of TOPSIS}

Four criteria have been considered for the study. Three of them have been categorized as the cost criteria such as total cost, air pollution, and noise pollution. The value of these cost criteria should be minimum for the maximum advantage. Another criterion has been considered as profit criteria and the value of these criteria should be maximum for the maximum advantage. The problem data shown in Table 5 has been normalized and shown in Table 9. The normalized data has been multiplied with their corresponding weights and has been shown in Table 10.

Table 9. Normalized decision matrix

\begin{tabular}{|l|c|c|c|c|}
\hline S.No. & Total cost & Air pollution & Noise pollution & Reliability \\
& C1 & C2 & 1 & 0 \\
\hline 1 & 0.642 & 1 & 0 & 0.25 \\
\hline 2 & 0.546 & 0 & 0 & 0.25 \\
\hline 3 & 0.230 & 0.6 & 0 & 0.25 \\
\hline 4 & 0.000 & 0.6 & 1 & 0.5 \\
\hline 5 & 1.000 & 1 & 1 & 1 \\
\hline 6 & 0.763 & 0.8 & 1 & 0.25 \\
\hline 7 & 0.263 & 1 & & 1 \\
\hline
\end{tabular}


International Journal of Mathematical, Engineering and Management Sciences

Vol. 5, No. 5, 913-925, 2020

https://doi.org/10.33889/IJMEMS.2020.5.5.070

Table 10. Weighted decision matrix

\begin{tabular}{|l|c|c|c|c|}
\hline S.No. & C1 & C2 & C3 & C4 \\
\hline 1 & 0.256 & 0.148 & 0.078 & 0 \\
\hline 2 & 0.217 & 0 & 0 & 0.093 \\
\hline 3 & 0.091 & 0.088 & 0 & 0.093 \\
\hline 4 & 0 & 0.088 & 0 & 0.093 \\
\hline 5 & 0.399 & 0.148 & 0.078 & 0.186 \\
\hline 6 & 0.304 & 0.118 & 0.078 & 0.373 \\
\hline 7 & 0.104 & 0.148 & 0.078 & 0.093 \\
\hline
\end{tabular}

Positive idle solution and negative idle solution have been calculated with the help of equations (4) and (5) and have been shown in Table 11.

Table 11. Positive idle solution and negative idle solution

\begin{tabular}{|l|c|c|c|c|}
\hline Max & 0.399 & 0.148 & 0.078 & 0.373 \\
\hline Min & 0 & 0 & 0 & 0 \\
\hline
\end{tabular}

The distances of each alternative from positive idle solution and negative idle solution have been calculated with the equations (6) and (7) and have been shown in Table 12 and Table 13.

Table 12. Distances of each alternative from positive idle solution

\begin{tabular}{|l|c|c|c|c|}
\hline S. No. & Alternative 1 & Alternative 2 & Alternative 3 & Alternative 4 \\
\hline 1 & 0.020 & 0 & 0 & 0.139 \\
\hline 2 & 0.033 & 0.021 & 0.0060 & 0.078 \\
\hline 3 & 0.094 & 0.0036 & 0.0060 & 0.078 \\
\hline 4 & 0.159 & 0.0036 & 0.0060 & 0.078 \\
\hline 5 & 0 & 0 & 0 & 0.034 \\
\hline 6 & 0.0090 & 0.0009 & 0 & 0 \\
\hline 7 & 0.087 & 0 & 0 & 0.078 \\
\hline
\end{tabular}

Table 13. Distances of each alternative from negative idle solution

\begin{tabular}{|l|c|c|c|c|}
\hline S. No. & Alternative 1 & Alternative 2 & Alternative 3 & Alternative 4 \\
\hline 1 & 0.065 & 0.021 & 0.0060 & 0 \\
\hline 2 & 0.047 & 0 & 0 & 0.0086 \\
\hline 3 & 0.0082 & 0.0077 & 0 & 0.0086 \\
\hline 4 & 0 & 0.0077 & 0 & 0.0086 \\
\hline 5 & 0.159 & 0.021 & 0.0060 & 0.034 \\
\hline 6 & 0.092 & 0.013 & 0.0060 & 0.139 \\
\hline 7 & 0.010 & 0.021 & 0.0060 & 0.0086 \\
\hline
\end{tabular}

The relative closeness of each alternative has been calculated by equation (8) and the ranking of all the alternatives has been done on the basis of their relative closeness in decreasing order. The relative closeness and the final rank of the alternatives have been shown in Table 14. 
International Journal of Mathematical, Engineering and Management Sciences

Vol. 5, No. 5, 913-925, 2020

https://doi.org/10.33889/IJMEMS.2020.5.5.070

Table 14. Relative closeness and ranking

\begin{tabular}{|l|c|c|c|c|}
\hline S. No. & $\mathrm{k}_{\mathrm{c}}{ }^{+}$ & $\mathrm{k}_{\mathrm{c}}{ }^{-}$ & $\mathrm{RC}$ & Ranking \\
\hline 1 & 0.39 & 0.30 & 0.43 & 3 \\
\hline 2 & 0.37 & 0.23 & 0.38 & 4 \\
\hline 3 & 0.42 & 0.15 & 0.26 & 6 \\
\hline 4 & 0.49 & 0.12 & 0.19 & 2 \\
\hline 5 & 0.18 & 0.46 & 0.71 & 1 \\
\hline 6 & 0.09 & 0.5 & 0.84 & 5 \\
\hline
\end{tabular}

\section{Result}

After solving the problem with the help of Fuzzy AHP and TOPSIS, it has been found that solar photovoltaic (PV)-diesel generator hybrid energy system got the highest rank among all the other alternatives and it means that solar photovoltaic (PV)-diesel generator hybrid energy system is the best alternative that can be used to supply power to a telecom tower at the selected location.

\section{Conclusions}

This paper deals with the comparison of different alternative solutions based on several criteria that can be used to supply $4 \mathrm{KW}$ continuous power supply to the telecom tower. Here, Fuzzy AHP and TOPSIS method have been used to solve this MCDM problem and it shows that solar photovoltaic (PV)-diesel generator hybrid energy system can be used as the best alternative over the conventional grid-diesel powered energy systems. It is because of the fact, as it has less running cost, less maintenance cost, can give a continuous power supply of $4 \mathrm{KW}$ to the telecom tower system throughout the year. This system is highly reliable and produces less pollution compared to conventional grid-diesel powered energy systems. The presented work deals with a real-life problem and a suitable system of the problem has been proposed over a number of other alternative solutions. The proposed system could also be installed on other similar locations in India and outside the country.

The government is also encouraging the use of renewable sources to overcome the challenges faced by the economy and environment due to increased diesel usage, and a hybrid energy system can be a solution to this problem. In near future governments may also provide some subsidy for solar energy equipment and the cost of these systems may further decrease. In future work, other types of renewable energy resources and many other types of solar collectors may also be included for getter better results at different sites. Many other optimization techniques and mathematical approaches for optimizing the cost and results. Other MCDM approaches could be used for improving the decision-making policies for installing such types of systems such as Fuzzy TOPSIS, M-TOPSIS, PROMOTHEE, ENTROPY, etc.

\section{Conflict of Interest}

The authors confirm that there is no conflict of interest to declare for this publication.

\section{Acknowledgment}

This research did not receive any specific grant from funding agencies in the public, commercial, or not-for-profit sectors. The authors sincerely appreciate the editor and reviewers for their time and valuable comments. 
International Journal of Mathematical, Engineering and Management Sciences

Vol. 5, No. 5, 913-925, 2020

https://doi.org/10.33889/IJMEMS.2020.5.5.070

\section{References}

Acakpovi, A., Hagan, E.B., \& Fifatin, F.X. (2015). Cost optimization of an electrical energy supply from a hybrid solar, wind and hydropower plant. International Journal of Computer Applications, 114(19), 4451.

Ajao, K.R., Oladosu, O.A., \& Popoola, O.T. (2011). Using HOMER power optimization software for cost benefit analysis of hybrid-solar power generation relative to utility cost in Nigeria. International Journal of Research and Reviews in Applied Sciences, 7(1), 96-102.

Alsharif, M.H., Nordin, R., \& Ismail, M. (2015). Energy optimization of hybrid off-grid system for remote telecommunication base station deployment in Malaysia. EURASIP Journal on Wireless Communications and Networking, 64, 1-15.

Amer, M., Namaane, A., \& M'sirdi, N.K. (2013). Optimization of hybrid renewable energy systems (HRES) using PSO for cost reduction. Energy Procedia, 42, 318-327.

Anayochukwu, A.V., \& Nnene, E.A. (2013). Simulation and optimization of hybrid diesel power generation system for GSM base station site in Nigeria. Electronic Journal of Energy \& Environment, 1(1), 37-56.

Ani, V.A. (2014). Optimal operational strategy for PV/wind-diesel hybrid power generation system with energy storage. International Journal of Energy Optimization and Engineering, 3(1), 101-120.

Avikal, S., Jain, R., \& Mishra, P.K. (2014). A Kano model, AHP and M-TOPSIS method-based technique for disassembly line balancing under fuzzy environment. Applied Soft Computing, 25, 519-529.

Bajpai, P., Prakshan, N.P., \& Kishore, N.K. (2009, January). Renewable hybrid stand-alone telecom power system modeling and analysis. In TENCON 2009 IEEE Region 10 Conference (pp. 1-6). IEEE. Singapore.

Chand, M., \& Avikal, S. (2015, November). An MCDM based approach for purchasing a car from Indian car market. In 2015 IEEE Students Conference on Engineering and Systems, (pp.1-4). IEEE. Allahabad, India.

Chand, M., Hatwal, D., Singh, S., Mundepi, V., Ratuti, V., Rashmi, \& Avikal, S. (2017, April). An approach for purchasing a sedan car from Indian car market under Fuzzy environment. In $6^{\text {th }}$ International Conference on Soft Computing for Problem Solving, (pp. 239-244), Patiala, India.

Çolak, M., \& Kaya, I. (2017). Prioritization of renewable energy alternatives by using an integrated fuzzy MCDM model: a real case application for Turkey. Renewable and Sustainable Energy Reviews, 80, 840853.

Ekren, B.Y., \& Ekren, O. (2009). Simulation based size optimization of a PV/wind hybrid energy conversion system with battery storage under various load and auxiliary energy conditions. Applied Energy, 86(9), 1387-1394.

Gabler, H., \& Luther, J. (1988). Wind-solar hybrid electrical supply systems. Results from a simulation model and optimization with respect to energy pay-back time. Solar and Wind Technology, 5(3), 239-247.

Gupta, S.C., Kumar, Y., \& Agnihotri, G. (2007, December). Optimal sizing of solar-wind hybrid system. In 2007 IET-UK International Conference on Information and Communication Technology in Electrical Sciences (ICTES 2007) (pp. 282-287). IET. Chennai, India.

http://www.synergyenviron.com/tools/solar-irradiance/uttarakhand

https://www.worldweatheronline.com/dehradun-weather-averages/uttarakhand/in.aspx 
International Journal of Mathematical, Engineering and Management Sciences

Vol. 5, No. 5, 913-925, 2020

https://doi.org/10.33889/IJMEMS.2020.5.5.070

Hwang, C.L., \& Yoon, K. (1981) Methods for multiple attribute decision making. In: Multiple Attribute Decision Making. Lecture Notes in Economics and Mathematical Systems, vol. 186. Springer, Berlin, Heidelberg.

Kusakana, K., \& Vermaak, H.J. (2013). Hybrid renewable power systems for mobile telephony base stations in developing countries. Renewable Energy, 51, 419-425.

Lal, D.K., Dash, B.B., \& Akella, A.K. (2011). Optimization of PV/wind/micro-hydro/diesel hybrid power system in HOMER for the study area. International Journal on Electrical Engineering and Informatics, $3(3), 307-325$

Lorincz, J., \& Bule, I. (2013). Renewable energy sources for power supply of base station sites. International Journal of Business Data Communications and Networking, 9(3), 53-74.

Martinez-Diaz, M., Villafafila-Robles, R., Montesinos-Miracle, D., \& Sudrià-Andreu, A. (2013, March). Study of optimization design criteria for stand-alone hybrid renewable power systems. In International Conference on Renewable Energies and Power Quality (pp. 1266-1270), Bilbao, Spain.

Moury, S., Khandoker, M.N., \& Haider, S.M. (2012, August). Feasibility study of solar PV arrays in grid connected cellular BTS sites. In 2012 International Conference on Advances in Power Conversion and Energy Technologies (pp. 1-5). IEEE. Mylavaram, Andhra Pradesh, India.

Muralikrishna, M., \& Lakshminarayana, V. (2011). A $10 \mathrm{Kw}$ combined hybrid (wind and solar photovoltaic) energy systems for isolated generating system. ARPN Journal of Engineering and Applied Sciences. 6(6). 99-104.

Ng, C.Y. (2016). Evidential reasoning-based fuzzy AHP approach for the evaluation of design alternatives' environmental performances. Applied Soft Computing, 46, 381-397.

Prasad, G.V.T., Srinivasan, S., \& Sriram, V. (2010). Hybrid solar and wind off-grid system - design and control. International Journal of Engineering Science and Technology, 2(4), 548-552.

Rath, S., Ali, S.M., \& Iqbal, M.N., (2012). Strategic approach of hybrid solar-wind power for remote telecommunication sites in India. International Journal of Scientific \& Engineering Research, 3(6), 1-6.

Zhou, W. (2008). Simulation and optimum design of hybrid solar-wind and solar-wind-diesel power generation systems. Hong Kong Polytechnic University. Hong Kong. 